\title{
LEGAL ANALYSIS OF THE IMPLEMENTATION OF RISK ALLOCATION IN COOPERATION SCHEMES WITH THE GOVERNMENT AND BUSINESS ENTITIES IN INFRASTRUCTURE PROVISION IN INDONESIA
}

\author{
Nabilah Rezkyna1, Pupung Faisal ${ }^{2}$, Purnama Trisnamansyah ${ }^{3}$ \\ 1,2,3 Padjadjaran University \\ Jl. Dipati Ukur No. 35, Lebakgede, Coblong District, Bandung City, West Java 40132 \\ Email: nrizkyna@gmail.com
}

\begin{abstract}
Risk allocation is a key feature in government-business partnerships. In the Public Private Partnership scheme, risk allocation is a difficult thing. The transfer of risk to the private sector has an impact on the price of the project. Likewise, allocating risk to the public sector which in practice tends to reduce Value For Money. In addition, project risk is dynamic and changes throughout the life of the project so it cannot be predicted with certainty. This normative research aims to examine the guiding principles for increasing the effectiveness of risk allocation and maximizing Value For Money from existing regulations in Indonesia and Government Cooperation agreements with Business Entities based on best practices in several other countries. The approach used in this paper uses a conceptual and comparative approach. The results obtained from this paper are that it is necessary to identify and anticipate risks including alternative solutions that are adjusted to the principle of risk allocation to minimize risk, as well as adjustments to the matrix that have been made by PT PII, risk allocation principles, best practices and related regulatory frameworks in Indonesia. Result, risks in KPBU projects are often an obstacle in the success of KPBU implementation in Indonesia. To minimize the risks that will be faced or may be faced, it is necessary to identify and anticipate risks including alternative solutions that are adjusted to the principle of risk allocation. In developing an effective risk matrix, innovative thinking is needed that is adapted to the characteristics of the KPBU project and the principles of risk management. This must also be adjusted to the matrix that has been made by PT PII, the principles of risk allocation, best practices and related regulatory frameworks in Indonesia are used as references. If properly implemented, this principle is expected to result in a lower risk premium and lower project costs, thus having a positive impact on the project's stakeholders.
\end{abstract}

Keywords: Government Cooperation with Business Entities; Risk Allocation; Value for Money.

\section{A. INTRODUCTION}

The government as the executor of a country's economic activities is responsible for providing basic needs, such as infrastructure, education, security, health in order to ensure

\footnotetext{
${ }^{1}$ Author identity

${ }^{2}$ Author identity

${ }^{3}$ Author identity
} 
economic growth in the public and private sectors. ${ }^{4}$ Through the right policies and commitments to infrastructure development, it is believed that this can help reduce poverty, overcome the problem of inter-regional and inter-regional disparities, strengthen food security, and reduce urbanization pressures which as a whole lead to improving the quality and welfare of the community. ${ }^{5}$

This infrastructure development certainly has a key role in the economic growth and competitiveness of a country. Starting from encouraging growth stimulation, facilitating community economic activities, distributing the flow of production of goods and services to encouraging investment and exports. ${ }^{6}$

There are several problems that can hinder infrastructure growth such as planning, coordination, use of weak analysis, political influence, and the existence of criminal acts of corruption. In addition, the large amount of development funds that must be provided for infrastructure development and the length of time required are obstacles in accelerating infrastructure development in developing countries, one of which is Indonesia. As a result of the limited funds

4 Caiyan Cui, et. Al., Review of Studies on the Public-Private Parternships (PPP) For Infrastructure Projects, "Internartional Journal of Project Management”, Vol. 36, 2018, 773-794,pgl. 773.

5 Sulistijo Sidarto dan Budi Santoso, Proyek Infrastruktur \& Senketa Konstruksi, (Jakarta: Kencana, 2018), pg. 2.

6 Christopher Willoughby, Infrastructure and The Millennium Development Goals: Complementarity of Infrastructure for Achieving the Millennium Development Goals, (Berlin: United Nations, 2004). available, the government opens the door to private sector involvement in the provision of infrastructure which is expected to bring efficiency in terms of both financial and technical aspects. ${ }^{7}$

The Public Private Partnership scheme (hereinafter referred to as "PPP") is an agreement between the government and one or more private parties. In this scheme, the private sector will receive benefits according to the services provided. One way to increase the effectiveness of its implementation depends on the transfer of risk between the government and the private sector itself. 8

PPP can also be interpreted as a "contractual relationship" where the private sector participates and is responsible for all or part of the government's functions in infrastructure development. In other words, PPP is a contractual agreement between the government and the private sector agency where all resources and risks will be shared proportionally in the context of providing and delivering public services. ${ }^{9}$ The existence of this scheme is also intended to close the financial gap that

7 Riham Shendy dan Zachary Kaplan dan Peter Mousley, Toward Better Infrastructure: Conditions, Constraints, and Opportunities in Financing Public-private Partnerships in Select African Countries, (Washington DC: The World Bank, 2011),pg. 3.

${ }^{8}$ Cliff Hardcastle dan Kate Boothroyd, Risk Overview in Public-Private Partnership, PublicPrivate Partnerships: Managing Risks and Opportunities Risks Overview in Public-Private Partnership (USA: Blackwell Science Ltd, 2003), pg. 31

$$
{ }^{9} \text { Ibid }
$$


occurs due to the insufficient government budget in financing infrastructure. ${ }^{10}$

In Indonesia, this scheme is regulated in Presidential Regulation Number 38 of 2015 concerning Government Cooperation with Business Entities in the Provision of Infrastructure (hereinafter referred to as "Presidential Regulation 38/2015"). This regulation regulates cooperation between government and business entities for certain infrastructure projects. The project covers transportation infrastructure, roads, water resources and irrigation, drinking water, wastewater management systems, solid waste management systems, telecommunications and informatics, electricity, oil and gas and renewable energy, energy conservation, urban facilities, educational facilities, and etc. ${ }^{11}$

The implementation of this KPBU is also stated in several other implementing regulations, such as Regulation of the Minister of National Development Planning (PPN) / Head of the National Development Planning Agency (Bappenas) Number 2 of 2020 concerning Procedures for Implementing KPBU in Infrastructure Provision (hereinafter referred to as "Ministerial Regulation 2 /2020"). In this provision, there is an explanation regarding the implementation of KPBU stages that must

10 Interview with Mr. Annafi Papandayan Muhammad Abduh, Directorate of Infrastructure Financing and Support Management of the Ministry of Finance of the Republic of Indonesia, October 25, 2020.

11 Indonesia, Presidential Regulation Number 38 of 2015 concerning Government be carried out by the Minister/Head of Institution/Head of Region as the Person in Charge of the Cooperation Project (hereinafter referred to as "PJPK") in order to achieve the objectives of the KPBU scheme itself.

To realize a successful and sustainable KPBU program, this KPBU scheme must be implemented with various arrangements that can provide certainty for both parties. In addition, there is a need for mechanisms and procedures to regulate the development and monitoring of agreements between the public and the private sector.

It should be noted that both the government and business entities have their respective interests that the parties want to achieve. Besides being as a partner of business entities in providing infrastructure, the government also has another role, namely as a subject of public law. ${ }^{12}$ The existence of this double role makes the government have a special position in contractual relationships, especially with regard to project implementation. ${ }^{13}$

In practice, there are still several factors that hinder the implementation of $\mathrm{KPBU}$, one of which is due to the ineffectiveness of allocation and mitigation in projects which often causes failure in infrastructure projects. ${ }^{14}$ Risks in the provision of KPBU infrastructure

Cooperation with Business Entities in Infrastructure Provision. Article 5 paragraph 2.

12 Yohanes Simamora, Hukum Perjanjian: Prinsip Hukum Kontrak Pengadaan Barang dan Jasa oleh Pemerintah, (Jakarta: Laksbang Pressindo, 2009), pg. 77.

13 Ibid

14 Ibid, pg. 34. 
are things that may occur during the validity of the cooperation agreement. This has led to the need for qualified capabilities in identifying and allocating risks as outlined in the KPBU agreement because this has a major role in the continuity and smoothness of the infrastructure provision process. Therefore, it is appropriate that this risk must be regulated in such a way that it does not harm either party in order to achieve the KPBU's own goals and principles. ${ }^{15}$

This risk management certainly involves and requires various techniques to identify, measure, allocate, transfer, and control project risks. However, in practice this risk management will differ depending on the participating objects and subjects. ${ }^{16}$

Cliff Hardcastle and Kate Boothroyd stated that there are various risks in the implementation of the KPBU which lead to the need for proper identification and allocation and transfer of risks in accordance with the capacity and integrity of each party to overcome these risks so that they can be handled optimally. ${ }^{17}$ The allocation and transfer of risk should not only be imposed on one party, especially the private sector. The existence of a disproportionate and unbalanced risk allocation arrangement

\footnotetext{
15 Ibid

16 Andrew Walsh, A Legal Perspective on Risk Management in Public-Private Partnerships, Public-Private Partnerships: Managing Risks and Opportunities Risks Overview in Public-Private Partnership (USA: Blackwell Science Ltd, 2003), hlm. 154

17 Cliff Hardcastle dan Kate Boothroyd, Op.Cit., pg. 48.
}

is considered contrary to the KPBU principle and has the potential to weaken the formation of a KPBU cooperation pattern in Indonesia.

Furthermore, the risk will be inappropriate to be transferred to the private sector if the private sector cannot manage it properly, resulting in higher handling costs. 18 If the government allocates risk without considering the ability of the private sector in overcoming these risks, this will actually reduce the value of the KPBU itself (value for money). ${ }^{19}$ It should also be borne in mind that this risk allocation is an incentive for the private sector to increase efficiency in providing the required services. Therefore, the government should identify risks in detail and comprehensively so that they are clearly defined in the clauses of the agreement to be agreed. ${ }^{20}$

\section{B. Problem Statement}

The formulation of the problem in this research is focused on how to guide principles to increase the effectiveness of risk allocation and how to maximize value for money from existing regulations in Indonesia and PPP agreements based on best practices in several other countries.

\section{c. Research Method}

To achieve the above objectives, this research will use a normative legal

\footnotetext{
18 Riham Shendy dan Zachary Kaplan dan Peter Mousley, Op.Cit., pg.3.

19 Jeremy Colman, Examining The Value For Money Deals Under The Private Finance Initiative, Vol. 15, Issue 4, (London: Stationery Office, 2000), pg. 72

${ }^{20}$ Ibid
} 
research method using a conceptual approach, statute approach and comparative approach.

\section{ANALYSIS and DISCUSSION}

\section{PUBLIC-PRIVATE PARTNERSHIPS CONCEPT}

\subsection{Public-Private Partnerships Concept Background}

There are many definitions put forward by experts and researchers about PPP. Akintola and Mathias stated that PPP is a form of long-term agreement between the private sector and government institutions that aims to utilize private resources and expertise for the provision and delivery of public services. $^{21}$ In this scheme, the private sector usually finances and operates the investment project in return for the parties receiving the provision of public facilities and services. ${ }^{22}$

PPP is closely related to the provision of public infrastructure. Infrastructure development through the PPP scheme can be the right solution in meeting the infrastructure needs of a country or region. In this context, the private sector is considered to have greater incentives and ability to provide and manage service costs more efficiently. ${ }^{23}$

In this collaboration, the government determines the quality and quantity of services that must be provided and fulfilled by private partners.

21 Akintola Akintoye, et. al, Public-Private Partnerships: Managing Risks and Opportunities, (USA: John Wiley \& Sons, 2008), pg. 154

22 Yusid Toyib dan Riant Nugroho, Transformasi Public Private Partnership Indonesia: Urgensi PPP Dalam Penyediaan Infrastruktur di
The main principle in PPP is related to the transfer of some risk from the Government to private partners. Risks are identified by the Government to be assessed and allocated to determine which can be transferred to private partners through an appropriate and fair payment mechanism. The PPP concept in infrastructure development is:

a. Infrastructure Service Usage-Based Structure (Usage Based PPP)

In this structure, the scope of infrastructure provision that is collaborated includes all roles or jobs that were previously the responsibility of the public sector. The Concession model structure is often used in several infrastructure sectors, such as toll roads, railways, ports and the utility sector. In this structure, PJPK has given concession rights or concessions to BUP in the context of providing infrastructure services for an agreed period of time. ${ }^{24}$

b. Structure Based Availability of Infrastructure Services

In this structure, the scope of infrastructure provision that is collaborated covers only a part of all roles or jobs that were previously the responsibility of the public sector. ${ }^{25}$ During the contract period, BUP will receive periodic payments from the PJPK for the availability of infrastructure facilities and services.

Indonesia. (Jakarta: Elex Media Komputindo, 2018), pg. 34.

\footnotetext{
${ }^{23}$ Akintola Akintoye, et. al, Op.Cit.

24 PT PII, Acuan Alokasi Risiko 2019, pg. 3.

25 Ibid, pg. 4.
} 
This periodic payment component includes return on investment (CAPEX), operational and maintenance costs (OPEX), and Return on Investment (ROI). ${ }^{26}$

This concept is usually applied to the form of Build, Operate, Transfer (BOT) or other forms as long as the ownership status of the assets at the end of the cooperation period will be wholly owned by the government. In this case, BUP is responsible for the availability of facilities from design, construction, financing and operation and maintenance (O\&M). ${ }^{27}$

c. Operation and Maintenance Agreement (O\&M Contract)

This concept of O\&M refers to a contract in which the business entity is the party who is given the right to manage the facility with responsibility for the operation, maintenance of certain infrastructure facilities. ${ }^{28}$ This concept can take the form of an affermage contract and a lease contract.

\subsection{Efforts to Regulate the Concept of Public Private Partnerships in Several Countries}

Different types of PPP are used in different countries depending on the characteristics, regulations and legal systems of each country. In general, these private parties are not paid directly by

\footnotetext{
${ }^{26}$ Ibid

27 Ibid

28 Ibid

29 Young Hoon Kwak, et al, Toward a Comprehensive Understanding of Public-Private
}

the government but they obtain their own financing for the construction.

\section{a. United Kingdom}

The implementation of publicprivate partnerships in the UK was developed in 1992 as the Private Finance Initiative ("PFI"). PFI was developed by the Private Finance Unit of the Office of Government Commerce's. The sanitation and water supply project is one of the projects carried out under a publicprivate partnership scheme in the UK. The procurement of military installations and toll roads in the UK has also used a government-private partnership scheme.

One of the most important factors in realizing value for money in this PFI concept is a detailed and appropriate risk analysis, faster project completion, project cost reduction, innovation in project development, and calculation of maintenance costs. Meanwhile, the factors that hinder this are too high costs for the PFI project procurement process, complex negotiations, difficulties in determining service quality, and potential conflicts of interest. $^{29}$

In the UK, the implementation of this risk allocation is carried out by first identifying the levels of risk, which consist of macro, meso and micro levels. Then, after carrying out

Partnerships for Infrastructure Development, California Review Management, Vol. 51., No. 2, 2009, pg. 58. 
the identification stage, risks that are at the macro and micro levels must be

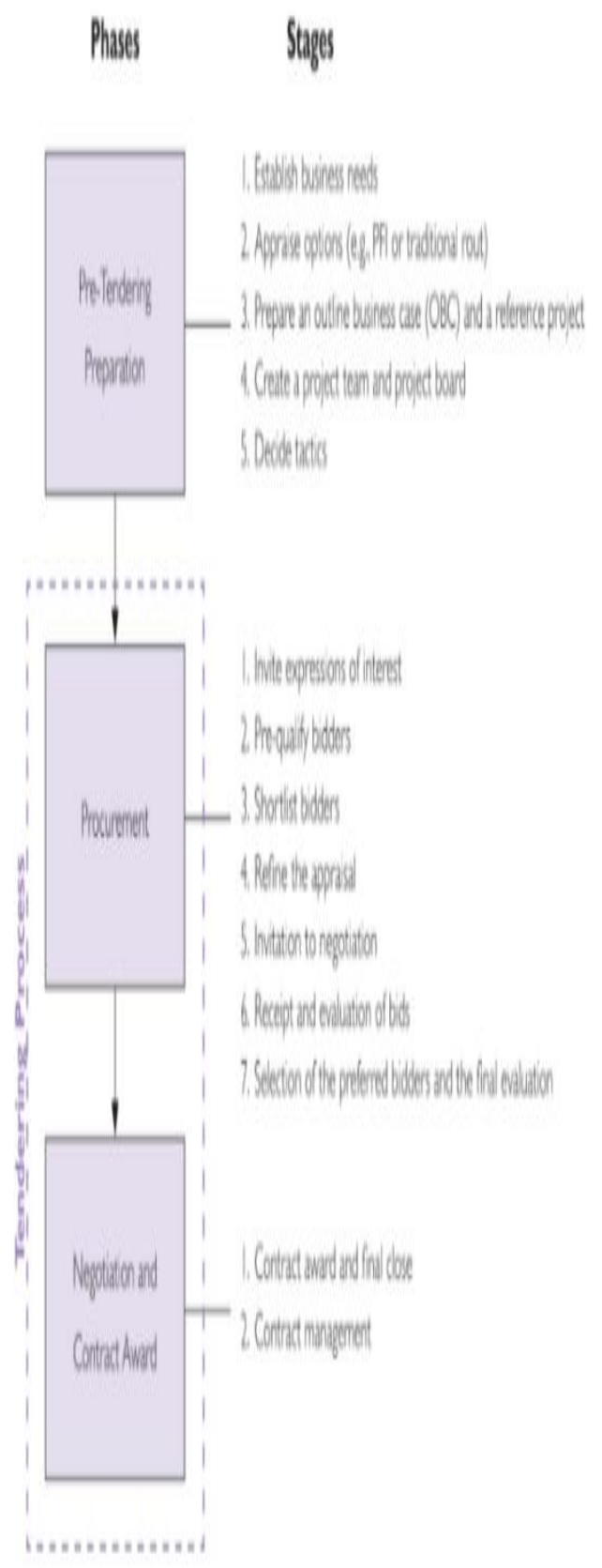

maintained or allocated to the public sector. Meanwhile, at the meso level,

${ }^{30}$ Ibid, pg. 67

31 Adrian Clough, The Public-Private Partnership Law Review: Third Edition, (United Kingdom: The Law Reviews, 2017), pg. 238. it should be allocated to the private sector. ${ }^{30}$

Furthermore, it is known that the private party in the PFI project is protected against the following events: 1) in the event of a breach of contract, the private party will receive compensation and relief from its obligations; 2) if an event occurs beyond the control of the private party, then get assistance from the default termination; and 3) in the event of a force majeure situation. ${ }^{31}$

b. United State

In the United States, the application of public and private cooperation has been applied in several fields, for example in the military field, including weapons and explosives. However, the procurement of installations in the military sector in the United States has several problems, among others, related to the secrecy of national defense which is vulnerable to being known by the public. The United States government also has regulations that support the implementation of public-private cooperation, namely the Patent Act, Small Business Innovation Development Act, Omnibus Trade and Competitiveness Act, and the Organic Act. ${ }^{32}$

In general, the United States does not offer government guarantees in PPP projects. In contrast to PPP

32 Ibid, pg. 247. 
projects in various developing countries, solvency is not the main consideration in PPP implementation. The United States provides the Transportation Infrastructure Finance and Innovation Act (TIFIA) in addition to financing for some PPP projects. ${ }^{33}$

Furthermore, if one looks at the distribution of risk for PPP projects in the United States, it can be seen that for each project delivery model, responsibility will be allocated to the private sector. Attached is a table that describes the risk allocations commonly used in PPP projects in the United States. ${ }^{34}$

\begin{tabular}{|c|c|c|}
\hline \multirow{11}{*}{ B } & Project delivery models & Functional responsibilitites and project risks \\
\hline & Design-build & Final deign, construction and construction inspection \\
\hline & Design-build with warranty & Final design, construction, construction inspection and long-term preservation \\
\hline & Operate and maintain & Maintenance and operations \\
\hline & Construction management at risk & Preliminary design, tinal designn, construction and construction inspection \\
\hline & Design-build-operate-mintain & $\begin{array}{l}\text { Finance, final design, construction, construction inspection, maintenance, } \\
\text { operations and traffic revenuc }\end{array}$ \\
\hline & Design-build-finance-operate & $\begin{array}{l}\text { Finance, final design, construction, construction inspection, maintenance, } \\
\text { operations and traffic revenue }\end{array}$ \\
\hline & Brownfield concession & Finance, maintenance, operations, long-term preservation and traffic revenue \\
\hline & Greenfeld concession & $\begin{array}{l}\text { Finance, final design, construction, construction inspection, maintenance, } \\
\text { operations, long-term preservation and traffic revenuc }\end{array}$ \\
\hline & Build-transfer-operate & $\begin{array}{l}\text { Finance, preliminary design, final design, construction, construction inspection, } \\
\text { maintenance, operations, long-term preservation and traffic revenuc }\end{array}$ \\
\hline & Build-own-operate-transfer & $\begin{array}{l}\text { Planning, environmental dearance, land acquisition, finance, prediminary design, } \\
\text { final deighn, construction, construction inspection, maintenance, operations, } \\
\text { longterm preservation, traffic revenue and asset ownership }\end{array}$ \\
\hline \multirow{3}{*}{ Non-PB } & Traditional design-bid-build & Final deign and construction \\
\hline & Build-own-operate & $\begin{array}{l}\text { Planning, environmental dearance, land acquisition, finance, prediminary design, } \\
\text { final deiggn, construction, construction inspection, maintenance, operations, long } \\
\text { term preservation, traffic revenuc and asset owneeship }\end{array}$ \\
\hline & Asset sale & $\begin{array}{l}\text { Finance, maintenance, operations, long-term preservation, traffic revenue and } \\
\text { asset ownership }\end{array}$ \\
\hline
\end{tabular}

2. PPP CONCEPT IN INDONESIA

\subsection{The Existence of PPP Practices and} Arrangements in Indonesia

In Indonesia, PPP is implemented under the Government and Business Entity Cooperation (KPBU) scheme. KPBU is a collaboration between the Government and Business Entities in the provision of infrastructure for the public interest by referring to the specifications that have been previously determined by the Minister/Head of Institution/Head of Region/BUMN/BUMD, which partly or wholly uses the resources of the Business Entity by taking into account the risk sharing between the parties. ${ }^{35}$

The legal basis for implementing KPBU is Presidential Decree 38/2015, Regulation of the Minister of PPN 2/2020, Regulation of the Head of LKPP Number 19 of 2015 concerning Implementation of Procurement of Business Entities in Government Cooperation with Business Entities in Infrastructure Provision (hereinafter referred to as "Regulation of Head of LKPP 19/2015") and other related regulations.

The implementation of special KPBU for the Availability Payment scheme at the provincial, district and city levels is supported by a legal umbrella from the Ministry of Home Affairs with the issuance of

35 Indonesia, Peraturan Presiden Nomor 38 Tahun 2015, Op.Cit., Pasal 1 
Minister of Trade Regulation Number 96 of 2016 concerning Payments for Service Availability in the framework of Government Cooperation with Business Entities in Infrastructure Provision.

In line with this, guarantees from the government are also provided by the government in order to increase the creditworthiness of projects. ${ }^{36}$ The provision of infrastructure guarantees is further regulated through Presidential Regulation Number 78 of 2010 concerning Infrastructure Guarantee in Government Cooperation Projects with Business Entities carried out through Infrastructure Guarantee Business Entities and Minister of Finance Regulation number 260/PMK.011/2010 concerning Instructions for Implementing Infrastructure Guarantee in Government Cooperation Projects with Business Entities.

Various problems that commonly occur in the implementation of KPBU revolve around the existence of a slow rate of return, limited financing from the lender, long land acquisition, immature project preparation, regulations that often change and are less adaptive, governance and institutions that do not reflect Good Investment Governance, differences

\footnotetext{
${ }^{36}$ Ibid, hlm. 2.

37 Ministry of Public Works and Public Housing of the Republic of Indonesia, "Kementerian PUPR Mendorong KPBU Dalam
}

in perceptions between PJPK and BUP, the capacity of regulators and PJPKs that have not been maximized, the distribution and identification of risks that have not been mapped to the maximum which leads to the slowness of projects with the KPBU scheme. ${ }^{37}$

\subsection{Government Facilities and Support in the Context of Government Cooperation with Business Entities}

a. Project Development Facility

This facility is a direct assistance provided by the Ministry of Finance of the Republic of Indonesia for PJPK. The assistance provided is in the form of procurement of consultants for the preparation and assistance of project transactions as stipulated in the Minister of Finance Regulation Number 73/PMK.08/2018 concerning Facilities for the Preparation and Implementation of Government and Business Entity Cooperation Project Transactions in Infrastructure Provision.

The scope of project preparation includes the preparation of the Feasibility Study and the preparation of all studies and/or supporting documents. Meanwhile, transaction assistance includes procurement of implementing business entities, signing of KPBU agreements, as well

\footnotetext{
Penyediaan

Infrastruktur", http://www.pu.go.id/berita/10800/Kementeria n-PUPR-Mendorong-KPBU-Dalam-PenyediaanInfrastruktur, accessed on November 13, 2020
} 
as obtaining financing for KPBU projects (financial close), as long as they are part of the responsibilities allocated to the GCA based on the KPBU Agreement.

Therefore, if the PJPK as the initiator of the KPBU project needs assistance from the government, it can apply for this facility before the preparation or preparation stage of the Final Business Case, which will then be paid in the form of reimbursement to the State-Owned Enterprise that carries out the facility. For KPBU projects that use this facility are Umbulan SPAM, Bandar Lampung City SPAM, Makassar - Pare Pare Railway, West Semarang SPAM, West, Central and East Palapa Ring Packages, etc.

b. Partial Construction Cost Eligibility Support or Viability Gap Fund

Feasibility support is a fiscal contribution in the form of cash to the KPBU project for part of the construction costs to the Implementing Business Entity. This is done to improve the financial feasibility of the KPBU project and to realize service tariffs that are affordable by the community. There are several project criteria that are eligible to apply for Feasibility Support, such as:

1. The cooperation project has met the economic feasibility but has not met the financial feasibility;

2. The cooperation project applies the user pay principle;
3. The total investment cost of the cooperation project is at least Rp. 100 billion;

4. The business entity is determined by the Cooperation Project Manager (PJPK) through an open and competitive auction process;

5. There is a scheme for transferring assets and/or their management from the business entity to the PJPK at the end of the cooperation period.

At this stage, the submission and acquisition process must go through the PJPK which can be carried out in the planning and preparation stages. If this support is approved, then the approval time is within the time span before the approval in principle until the formation of the Implementing Business Entity.

Apart from that, in the context of providing Feasibility Support, the Minister of Finance has also established a Feasibility Support Committee through the Decree of the Minister of Finance Number 340/KMK.011/2013 which was amended by KMK Number 732/KMK.08/2015 chaired by the Director General of PPR.

c. Infrastructure Guarantee (Government Guarantee) by PT PII

This Infrastructure Guarantee is intended to guarantee political risk from 
both central and regional governments as the person in charge of the cooperation project to provide certainty and comfort for investors in investing. The legal basis for this infrastructure guarantee is Presidential Regulation Number 78 of 2010, Minister of Finance Regulation Number 260/PMK.011/2010, Minister of Finance Regulation Number 8/PMK/2016.

The risks that may be guaranteed in infrastructure investment in the KPBU scheme are Pre-Construction, Construction and Operation. For example delays in providing access to project land, budget approval for projects, discriminatory legal changes, delays in approval, payment for service availability, etc. Guaranteed these risks will certainly have a direct impact on increasing the bankability of a project.

d. Availability Payment

Payment for the availability of this service is a periodic payment by the PJPK to BUP for the availability of infrastructure services in accordance with the quality and/or criteria as specified in the KPBU Agreement during the operation period as regulated in PMK Number 260/PMK.08/2016 concerning Payment Procedures for
Service Availability on the KPBU Project. There are several criteria that a project must have in order to apply for this facility, such us:

1. economic and social infrastructure projects that have great benefits for the community as service users;

2. the return on investment does not come from payments by users for service rates;

3. in the event that the KPBU project receives income from payments by users of service tariffs, the PJPK cannot calculate the amount of income from payments by service users to carry out payments for service availability to the implementing business entity; and

4. The procurement of business entities is carried out through fair, open and transparent selection stages, and pays attention to the principles of fair business competition.

The advantages of this scheme are that it increases the attractiveness of KPBU projects for investors, allows PJPKs to acquire infrastructure without having to provide large funds at the beginning of the project for construction, BUP does not bear demand risk, certainty of investment returns, and the project's financial feasibility is more secure. 


\subsection{Mechanism of Implementation of} Government Cooperation with Business Entities

Basically, each process of establishing and implementing a KPBU scheme is different depending on the type of infrastructure to be built and requires each sectoral consideration. However, in general, the implementation of KPBU can discuss several general things, starting from:

\section{Parties involved in KPBU}

There are several parties who may be involved and have an interest in the PPP scheme, including: (1) the Person in Charge of the Cooperation Project or PJPK, who can be the Minister/Head of Institution/Head of Region, or State-Owned Enterprise/Regional Owned Enterprise as provider or infrastructure providers; (2) Business Entities are State-Owned Enterprises, Regional-Owned Enterprises, private business entities in the form of Limited Liability Companies, foreign legal entities, or cooperatives; 38 and (3) KPBU Implementing Business Entity, which is a Limited Liability Company established by the Business Entity winning the auction or appointed directly. ${ }^{39}$

2. PPP implementation stages

38 Indonesia, Presidential Regulation Number 38 of 2015, Article 1 paragraph 7

39 Indonesia, Presidential Regulation Number 38 of 2015, Article 1 paragraph 8
To overcome all possible risks or problems that will occur in the KPBU project, KPBU is carried out in a structured and hyper-regulated manner considering that the provision of this infrastructure has an impact on various sectors of life. The KPBU implementation process based on Permen PPN 2/2020 can be described as follows:

a. PPP Project Planning

The initial stage to provide infrastructure with a KPBU scheme starts from the planning stage ${ }^{40}$ In this stage, there are at least seven stages that must be carried out in KPBU planning activities as stipulated in Permen PPN 2/2020, namely the preparation of the KPBU fund budget plan, identification and determination of the KPBU, budgeting of funds at the planning stage, public consultation, decision-making to continue or discontinue the plan. KPBU, compilation of KPBU plans list and KPBU categorization. ${ }^{41}$

In this planning stage, it is necessary to approach needs analysis, fit criteria and factor criteria by considering the suitability of the project with the RPJMN/D, the suitability of the project location with the Regional Spatial Plan, linkages between

40 Indonesia, Regulation of the Minister of National Development Planning Number 2 of 2020, Article 10 paragraph 1

41 Indonesia, Regulation of the Minister of National Development Planning No. 2 of 2020, Article 14 
infrastructure and inter-regional sectors, analysis of costs and social benefits. ${ }^{42}$ These stages tend to be carried out by the initiator, either by the PJPK or BUP in the form of a cost and value for money analysis of a project which will later produce a preliminary study document and a list of project priorities. ${ }^{43}$

b. Project Preparation

After planning, then further assessment and action is carried out. This stage is also known as project preparation. This stage consists of preparing a prefeasibility study including BUP investment returns, Submission of Government Support and/or Government Guarantees, submission of KPBU location determination. ${ }^{44}$ In carrying out the KPBU preparation, the PJPK is obliged to conduct an assessment of market interest or market sounding. ${ }^{45}$ This stage will result in a preliminary study and a final pre-feasibility study, government support plans, determination of procedures for BUP investment

42 Interview with Ms. Deandra Levina, Directorate of Development Funding for Development Ministry of National Development Planning/National Development Planning Agency (Bappenas), October 07, 2020.

43 Ibid

44 Indonesia, Regulation of the Minister of National Development Planning No. 2 of 2020, Article 23 paragraph 2

45 Indonesia, Regulation of the Minister of National Development Planning No. 2 of 2020, Article 10 paragraph 4 returns, land acquisition for KPBU. 46

c. KPBU Project Transaction

The project transaction stage consists of the completion of the pre-feasibility study which includes the final pre-feasibility study and the draft of the Business Entity procurement plan; ${ }^{47}$ as well as a public auction of a Business Entity which includes the planning and implementation of a public auction of a Business Entity. At this stage, negotiations, the signing of the KPBU agreement, to the fulfillment of infrastructure provision financing (financial close) are carried out. ${ }^{48}$ This stage will produce a cooperation agreement document, a government guarantee document and a regress document between the PJPK and the Government.

d. Execution of Agreement

Based on Permen PPN $2 / 2020$, this implementation stage consists of preparing to control the implementation of the KPBU agreement and controlling the implementation of the KPBU agreement. In the preparation

46 Sri Bagus Guritno, Policy for Providing Infrastructure Through KPBU (presented at the Ministry of National Development Planning/Bappenas Webinar, September 08, 2020

47 Indonesia, Regulation of the Minister of National Development Planning No. 2 of 2020, Article 31

\section{Ibid}


stage for controlling the implementation of the KPBU agreement, it consists of the appointment of the Control Team, preparation and determination of the instructions for controlling the implementation of the KPBU agreement, submission of all forms of documentation in all stages to the Control Team, coordination with the KPBU team in the implementation of activities related to the fulfillment of payments..49

\subsection{Application of Risk Allocation in Indonesia}

Talking about KPBU, it is necessary to pay attention to the high risk. From a theoretical level, risk is an event of uncertainty that has an impact on the achievement of goals. In other words, risk can be interpreted as an uncertainty about the achievement of the objective (target) that results in a deviation from what is expected. 50

In the context of infrastructure investment, risks can be divided from several points of view. From an investor's point of view, risk is a condition where investors may fail to achieve their return on investment targets, including the profits from investing a certain amount of funds

${ }^{49}$ Indonesia, Regulation of the Minister of National Development Planning No. 2 of 2020, Article 39B pg. 149.

${ }^{50}$ Yusid Toyib and Riant Nugroho, Op. Cit.,

51 Interview with Ms. Deandra Levina, Directorate of Development Funding for Development Ministry of National Development for infrastructure development. Meanwhile, from the government's point of view, risk is a condition when the government is unable to provide infrastructure or public services in accordance with the provisions of laws and regulations. ${ }^{51}$

Risks in the provision of KPBU infrastructure are actually events that may occur in the cooperation project during the validity of the cooperation agreement, which can negatively affect the investment of the business entity, either in the form of equity or third party loans. ${ }^{52}$

Risks in KPBU projects are often an obstacle in implementing KPBU in Indonesia. To minimize the risks that will be faced or may be faced, it is necessary to have the ability to identify and anticipate risks including alternative solutions.

In general, the implementation of a good risk allocation must be considered through a risk assessment since the KPBU project preparation stage. This risk assessment is part of the documents that will later become the basis for drafting the KPBU agreement. From a schematic perspective, the risk management process in the KPBU scheme is: 53 
1. KPBU project risk management begins with determining the scope of management according to the targets to be achieved by the government as the PJPK. For example, risk management which includes the preparation of risk mitigation plans and projects that have a high level of bankability in terms of risk allocation

2. Identification of PPP project risks using the checklist method, field observations and discussions with related parties.

3. Assessment of the risks that also includes the impact of the risk along with the estimation of the probability of the occurrence of the risk. This assessment uses several methods, one of which is direct environmental observation. Not only that, historical data evaluation and discussions with various related parties are also needed.

4. Risk evaluation which includes determining priorities where it will be evaluated which risks are the main concerns of PJPK and BUP. At this stage, the results of the risk analysis are reviewed with the agreed risk criteria. whether the risks are acceptable or unacceptable, whether it is an issue that should be watched out for or not, so that mitigation or handling of the issue needs to be

54 Ibid, pg. 151.

55 Interview with Mr. Muryata, Head of the Sub-Directorate of Investment Cooperation Coordination of the Directorate General of Public done. ${ }^{54}$ Furthermore, in order to deal with risks in KPBU projects, it is necessary at least three measures that can be taken, such as risk transfer to third parties (risk sharing); risk acceptance; risk mitigation, which can be done by reducing the possibility, or impact of the risk received.

5. Risk handling. At this stage, the PJPK uses the allocation matrix reference documents to facilitate the evaluation of the risk allocation included in the KPBU agreement which is then submitted and negotiated with the private sector.

6. The last stage is risk monitoring. This stage is carried out after the KPBU Agreement is formed to ensure that the risk mitigation plan that has been designed can run effectively.

The previously identified risk events are then re-evaluated using the risk allocation matrix created for each sector and sector by considering the following: 55

1. Risks must be allocated to those who are best able to control the likelihood and impact of the risk occurring.

2. Partial risk allocation leads to greater incentives for the private sector.

3. Risk allocation must also be allocated to the party who is best

Works and Housing Infrastructure Financing, Ministry of Public Works and Public Housing on November 6, 2020 
able to manage risk at the lowest cost.

4. It must be informed and confirmed based on market conditions.

5. To overcome the risk of variability, risk allocation should be done flexibly.

To see this, it is necessary to pay attention to the risk variables that affect the construction and management of a project and how to mitigate the risk of its implementation. Various incentives, support and government guarantees are also important to be given to a project in order to support the smooth implementation of the project.

Therefore, in developing an effective risk matrix, innovative thinking is needed that is adapted to the characteristics of the KPBU project and the principles of risk management. This must also be adjusted to the matrix that has been created by PT PII and the principle of risk allocation. Not only that, best practice events and related regulations also become references that must be used. If this risk allocation is implemented properly, it is believed that it can provide and generate a low risk premium and also result in lower project costs. This certainly has a positive impact, directly or indirectly, for the project stakeholders, one of which is the PJPK, BUP, sponsors and lenders.

\section{CONCLUSION}

Risks in KPBU projects are often an obstacle in the success of KPBU implementation in Indonesia. To minimize the risks that will be faced or may be faced, it is necessary to identify and anticipate risks including alternative solutions that are adjusted to the principle of risk allocation.

In developing an effective risk matrix, innovative thinking is needed that is adapted to the characteristics of the KPBU project and the principles of risk management. This must also be adjusted to the matrix that has been made by PT PII, the principles of risk allocation, best practices and related regulatory frameworks in Indonesia are used as references. If properly implemented, this principle is expected to result in a lower risk premium and lower project costs, thus having a positive impact on the project's stakeholders.

\section{REFERENCE}

\section{Books}

Akintoye, A (et al). Public Private Partnerships: Managing Risks and Opportunities. USA: John Wiley \& Sons, 2008.

Bauby, P (et al). France: Public-Private Partnerships In Water Sanitation And Public Transport" dalam Sharing Concerns: Country Case Studies in Public- Private Partnerships. Newscastle: Cambridge Scholars Publishing, 2018

Clough, A (et al). The Public-Private Partnership Law Review: Third 
Edition, United Kingdom: The Law Reviews, 2017

Hardcastle, C. \& Boothroyd, K. Risk Overview in Public-Private Partnership, Public-Private Partnerships: Managing Risks and Opportunities Risks Overview in Public-Private Partnership. USA: Blackwell Science Ltd, 2003.

Shendy, R., Kaplan, Z., \& Mousley, P. Toward Better Infrastructure: Conditions, Constraints, and Opportunities in Financing Publicprivate Partnerships in Select African Countries. Washington D.C: World Bank, 2011.

Sidarto, S. \& Santosa, B. Proyek Infrastruktur dan Sengketa Konstruksi. Jakarta: Kencana, 2018.

Simamora, Yohanes. Hukum Perjanjian: Prinsip Hukum Kontrak Pengadaan Barang dan Jasa oleh Pemerintah. Jakarta: Laksbang Pressindo, 2009.

Toyib, Y. \& Nugroho, R. Transformasi Public Private Partnership Indonesia: Urgensi PPP Dalam Penyediaan Infrastruktur di Indonesia. Jakarta: Elex Media Komputindo, 2018.

Walsh, A. A Legal Perspective on Risk Management in Public-Private Partnerships, Public-Private Partnerships: Managing Risks and Opportunities Risks Overview in Public-Private Partnership. USA: BlackWell Science Ltd, 2003.

Willoughby, C. 2004. Infrastructure and The Millennium Development Goals: Complementarity of Infrastructure for Achieving the Millennium
Development Goals. Berlin: United Nations, 2001.

World Bank. World Development Report: Trading for Development in the Age of Global Value Chains. Washington D.C: World Bank Group, 2020.

\section{Journal}

Cui, Caiyan (et al). Review of Studies on the Public-Private Parternships (PPP) For Infrastructure Projects, "Internartional Journal of Project Management, Volume 36, 2018, 773-794

Colman, J. Examining The Value For Money Deals Under The Private Finance Initiative. "Stationery Office", Volume 15, Isu 4, 2000.

Kwak, Y. (et al). Toward a Comprehensive Understanding of Public-Private Partnerships for Infrastructure Development. California Review Management, Vol. 51., No. 2, 2009

\section{Internet}

Ministry of Public Works and Public Housing of the Republic of Indonesia , "Kementerian PUPR Mendorong KPBU Dalam Penyediaan Infrastruktur", http://www.pu.go.id/berita/10800 /Kementerian-PUPR-MendorongKPBU-Dalam-PenyediaanInfrastruktur, accessed on November 13, 2020 